\title{
POLA KOMUNIKASI DALAM KRISIS PERNIKAHAN PADA PRAMUGARI MASKAPAI INTERNASIONAL
}

\author{
Julia Ratnasari Dewi \\ LSPR Communication \& Business Institute, Jakarta, Indonesia. \\ juliaratnasd@hotmail.com
}

\begin{abstract}
The phenomenology of women with a career as a Flight Attendant was observed to overcome difficulties in communication with their husbands, which created a crisis in their marriage, which makes the researcher interested to raise this topic. The crisis in marriage starts from a misunderstanding in the communication. When the differences begin to arise is not done through excellent communication, often to be ignored so that it continues growth until separated. This study aims to look at the ten communication patterns of relational development model in a relationship when it begins, grows, survives and ends - starting from the five stages of coming together and followed by five stages of coming apart. The method used in this study is qualitative and supported by relational development model with some characteristics of interpersonal communication. The results of the study show that all flight attendants experienced all the elements in the stage of coming together with excellent communication and interaction. Two flight attendants reached the end element of coming apart, which is terminating (divorce). One flight attendant survived through marriage counseling, and one flight attendant stuck in the avoiding stage. The cause is from various factors.
\end{abstract}

Keywords: interpersonal communication, marriage communication, relational development model, social construction theory

\begin{abstract}
Abstrak
Fenomena wanita dengan profesi Pramugari ditemukan seringkali mengalami hambatan dalam berkomunikasi dengan pasangannya yang menyebabkan krisis dalam pernikahannya telah mengusik peneliti untuk mengangkat topik ini. Krisis dalam pernikahan dimulai dari kesetidakpahaman dalam berkomunikasi. Dimana saat perbedaan mulai timbul seringkali tidak diselesaikan melalui komunikasi yang baik, melainkan diacuhkan sehingga terus berkembang sampai tahap berpisah. Penelitian ini bertujuan untuk melihat pola komunikasi relational development model pada saat sebuah hubungan dimulai, bertumbuh, bertahan, dan sampai berakhir. Dimulai dari lima tahap coming together dan diikuti dengan lima tahapan coming apart. Metode yang digunakan dalam penelitian ini adalah kualitatif dengan relational development model dan disertai menggunakan lima aspek yang terdapat pada komunikasi interpersonal. Hasil penelitian menunjukkan bahwa semua pramugari mengalami semua elemen dalam tahap coming together dengan komunikasi dan interaksi yang baik. Semua pramugari pernah mencapai tahap coming apart, dua pramugari mencapai elemen terakhir dari coming apart yaitu terminating (bercerai). Satu pramugari memasuki tahap stagnating dan dapat melalui krisis pernikahan melalui konseling perkawinan, sementara satu pramugari terjebak dalam tahap avoiding. Penyebabnya dari berbagai faktor.
\end{abstract}

Kata kunci: komunikasi interpersonal, komunikasi dalam pernikahan, relational development model, teori kontruksi sosial

\section{PENDAHULUAN}

Sejalan dengan perkembangan hidup manusia, setiap manusia ingin mengalami perkembangan hidup kearah yang lebih sempurna. Salah satu tahap perkembangan dalam kehidupan manusia adalah menikah. Hurlock (2002, pg. 290) menjelaskan bahwa tahapan perkembangan dimana tujuan besar 
dari seorang wanita yang belum menikah adalah tahapan untuk menjalani pernikahan dimana diperlukan penyesuaian perkawinan yang dilakukan antara suami dan istri dengan melakukan penyesuaian seksual, penyesuaian keuangan dan penyesuaian dengan keluarga dari pihak pasangan. Menikah adalah tahapan dari kehidupan yang merupakan suatu usaha untuk membina hubungan dengan lawan jenis untuk sebuah tujuan yang baik.

Pernikahan memiliki makna yang sangat sakral dan suci namun sebagian dari manusia ada yang menganggap kalau pernikahan hanyalah sekedar menyatukan dua insan, padahal jika manusia lebih memahami arti pernikahan itu secara kompleks maka mereka akan selalu mendapatkan kebahagian hidup dalam rumah tangga yang akan mereka bina dan tentunya tidak akan terjadi perceraian jika manusia benar-benar memahami arti sebuah pernikahan.

"Komunikasi adalah nyawa bagi suatu pernikahan." (Parrott dan Parrott, 1995). Sebelum memasuki gerbang pernikahan ditetapkan bersama visi, misi, perencanaan jangka pendek, menengah dan panjang untuk mencapai tujuan rumah tangga yang diinginkan melalui komunikasi.

Di dalam kehidupan sehari-hari setiap manusia saling berkomunikasi satu dengan yang lain dengan menggunakan bahasa yang dapat dimengerti oleh setiap pihak. Sebelum menikah, setiap pasangan sudah melihat, mengetahui, mempelajari dan menerima perbedaan latar belakang dari masingmasing pasangannya. Komunikasi terbuka secara dua arah harus mulai dilakukan sejak proses pacaran sampai memutuskan untuk melanjutkan ke jenjang pernikahan, kemudian berkembang setelah menikah dan dilanjutkan secara berkesinambungan.

Kegagalan dalam memahami pesan yang disampaikan dalam komunikasi antar pasangan suami istri yang terjadi dapat menjadi pemicu awal yang menyebabkan terjadinya krisis komunikasi dalam rumah tangga. Gejala awal ini yang seringkali diacuhkan dan dibiarkan sehingga terbentuk menjadi krisis yang semakin rumit untuk diselesaikan (Luthfi, 2017). Perbedaan dan kebuntuan dalam berkomunikasi seringkali disalahkan dan dijadikan alasan utama untuk mengakhiri pernikahan. Padahal tidak ada perceraian yang terjadi dalam semalam. Ada proses panjang sebab akibat sebelum pasangan suami-istri memutuskan untuk bercerai. Paputungan (2015) mengungkapkan dalam penelitiannya bahwa komunikasi merupakan salah satu faktor kepuasan dalam pernikahan.

Melihat fenomena perceraian yang khususnya terjadi di kalangan wanita dengan profesi pramugari. Wanita dengan profesi ini memiliki karir bagus sebagai pemimpin, mengepalai tim dalam sebuah penerbangan dengan rute internasional, memiliki kehidupan mapan, stabil dan mandiri dalam hal keuangan yang kemudian memutuskan untuk menikah, tidak menjadi jaminan akan langgeng dalam mengarungi bahtera pernikahannya. Pekerjaan ini memiliki tingkat perceraian tinggi, yaitu 50,5\% (Saunders, 2017, December 5). Beberapa diantaranya seringkali mengalami hambatanhambatan dalam berkomunikasi dengan pasangannya yang menyebabkan krisis dalam pernikahannya. Pengamatan yang dilakukan akan kemandirian yang dimiliki wanita dengan profesi ini terkadang juga mempengaruhi cara berkomunikasi dan berinteraksi dengan pasangannya.

Berdasarkan data yang dimuat sebuah situs web (liputan6, 2018), dengan judul, '7 Jenis Pekerjaan dengan Tingkat Perceraian Tinggi' memberi tahu bahwa orang-orang di industri perjalanan, yang mencakup profesi pramugari biasanya memiliki tingkat perceraian yang lebih tinggi daripada pekerjaan lainnya. Dalam situs tersebut, dijelaskan bahwa profesi pramugari cukup menentukan dalam menjadi penyebab perceraian, karena kurangnya waktu bersama dengan pasangannya. Pramugari memiliki tanggung jawab untuk selalu bepergian sesuai dengan jadwal yang ditentukan yang bisa 
saja terjadi timbulnya godaan untuk menjalin hubungan dengan sesama anggota kru. Dimana profesi pramugari biasanya lebih luwes dalam bersosialisasi yang terkadang seringkali diartikan "too friendly" yang mungkin kurang disukai oleh pasangannya. Selain waktu dan perselingkuhan, faktor perbedaan sosialekonomi disinyalir juga memiliki pengaruh. Faktor ekonomi yang tidak seimbang atau mungkin lebih tinggi bisa menjadi pengaruh karena tanpa disadari wanita dengan profesi ini merasa mandiri dan dapat memenuhi segala kebutuhannya tanpa bergantung pada pasangannya (suami) yang menyebabkan pasangannya merasa kurang dihargai.

Yuliati (2012) melakukan penelitian yang dilatar belakangi oleh fenomena dosen sebagai perempuan bekerja dalam memaknai dan membangun perkawinannya. Dalam penelitiannya digunakan berbagai teori sebagai kerangka pemikiran salah satunya adalah konstruksi sosial. Hasil penelitian menunjukkan bahwa perilaku menikah merupakan tindakan berkesadaran. Perilaku menikah didasarkan pada tujuan-tujuan yang ingin dicapai yang dikelompokkan menjadi tujuan normatif, psikologis, sosial dan ekonomi.

Penelitian Yuliati sejalan dengan teori konstruksi sosial (social construction) yang dicetuskan oleh Peter. L Berger dan Thomas Luckmann, menurut Littlejohn dan Foss (2009, p. 892) terdiri dari tiga bagian yaitu, sosial, konstruksi, dan realita. Pertama, sosial merupakan implikasi dari teori konstruksi sosial dimana suatu realitas sosial membutuhkan interaksi antar individu. Interaksi yang dimaksudkan adalah mengandung unsur kolaboratif, dimana terdapat tujuan yang menjadi kepentingan individu atau bersama. Melalui kolaborasi dengan sesama individu terciptalah pemahaman yang mengalir dari satu generasi kegenerasi lainnya. Dengan demikian, individu yang mempunyai kepentingan pasti mengkonstruksi dan hal ini terjadi dikarenakan adanya kata, aksi, objek, dan saluran (channel).

Kedua adalah konstruksi, menurut
Littlejohn dan Foss (2009, p. 892) konstruksi sosial memiliki empat tahap yaitu pertama konstruksi dimana individu menangkap suatu pengalaman dan memprosesnya hingga kemudian menjadikan suatu nilai, makna, serta pengetahuan yang dimilikinya selama hidup bersosialisasi berusaha untuk dipertahankan dalam kehidupannya. Bagian ketiga adalah realita itu sendiri. Dikemukakan oleh Littlejohn dan Foss (2009, p.893) realita dipisahkan menjadi dua yaitu realita secara fisik yang dapat dilihat atau disentuh dan realita sosial yang membutuhkan proses konstruksi atau membentuk pemahaman seperti tata tertib, norma, agama, hubungan dan lainnya yang merupakan bagian dari kehidupan individu dan diciptakan oleh individu itu sendiri. Hal ini sejalan dengan fenomena yang peneliti lakukan tentang profesi pramugari, dimana peneliti mengamati pola komunikasi yang terjadi antara pramugari dengan pasangannya. Profesi Pramugari tersebut merupakan bentuk konstruksi sosial dari karir yang dijalani dan juga sebagai seorang istri yang dibentuk dari pola komunikasi dalam pernikahan yang terjadi antara Pramugari dan pasangannya.

Dalam mengelola hubungan, perlu juga untuk memperhatikan komunikasi interpersonal. Dalam penelitian Dewi dan Sudhana (2013), menunjukkan adanya hubungan yang signifikan antara komunikasi interpersonal dengan keharmonisan pernikahan. Selain itu, keharmonisan dari sebuah pernikahan tergantung dari kondisi hubungan interpersonal pasangan suami istri, hubungan tersebut dapat terjalin dengan baik melalui komunikasi yang efektif antara suami dan istri.

Dalam penelitian ini, untuk menjelaskan komunikasi interpersonal yang terbentuk bagi Pramugari dan pasangannya, peneliti menggunakan konsep komunikasi interpersonal yang digagas oleh DeVito (Sugiyo, 2005 : 4), mengemukakan bahwa dalam komunikasi interpersonal meliputi lima aspek: Keterbukaan (openness) berupa kemauan menanggapi dengan senang hati informasi yang diterima. 
Kualitas keterbukaan mengacu pada tiga aspek dari komunikasi interpersonal, yaitu harus terbuka kepada komunikannya; kesediaan komunikator untuk bereaksi secara jujur terhadap stimulus yang datang; dan komunikator mengakui bahwa perasaan dan pikiran yang diungkapkannya adalah miliknya dan bertanggung jawab atasnya.; Empati(empathy) merupakan kemampuan untuk mengetahui apa yang sedang dialami orang lain pada suatu keadaan tertentu. Orang yang berempati mampu memahami motivasi, pengalaman, perasaan, sikap, serta harapan dan keinginan orang lain sehingga dapat mengkomunikasikan empati, baik secara verbal maupun non-verbal.; Dukungan (supportiveness) Sikap mendukung ini berupa dorongan secara positif baik verbal maupun non-verbal (seperti sentuhan untuk menenangkan) terutama ketika lawan bicara sedang mengalami permasalahan. Individu memperlihatkan sikap mendukung dengan bersikap deskriptif bukan evaluatif, spontan bukan strategik.; Rasa positif (positives) Yaitu perasaan positif yang harus dimiliki seseorang terhadap dirinya, agar mendorong orang lain lebih aktif berpartisipasi, dan menciptakan situasi komunikasi kondusif untuk interaksi dua arah yang efektif. Kesetaraan atau kesamaan (equality) Suasana yang setara akan membuat komunikasi antarpribadi lebih efektif. Kesetaraan yaitu pengakuan bahwa kedua belah pihak saling menghargai, berguna, dan mempunyai sesuatu yang penting untuk disumbangkan. Kesetaraan meminta individu untuk memberikan penghargaan positif tak bersyarat kepada individu lain. Kelima aspek tersebut dibutuhkan dalam komunikasi interpersonal antara pasangan suami istri.

Brody, Lavebre, dan Blackburn (2016) meneliti struktur faktor perilaku relasional di situs jejaring sosial, hubungan antara perilaku, kualitas relasional dan proses awal sampai pemutusan hubungan. Studi ini memperluas pemahaman tentang bagaimana teknologi mencerminkan cara orang berinteraksi dengan menggunakan relational development model. Gagasan bahwa ada tahapan dalam pengembangan sebuah hubungan yang ditandai dengan pola komunikasi yang berbeda bukanlah hal baru. (Knapp, 2014 : 48) telah mengembangkan salah satu model tahapan relasional dalam pengembangan relasi interpersonal.

Selanjutnya, peneliti mengadaptasi relational development model ini untuk melihat pola komunikasi yang terjadi antara Pramugari dan pasangan. Hubungan interpersonal Pramugari dan pasangannya dipetakan dalam sepuluh tahapan yang dibagi dalam dua fase yaitu, lima fase coming together, dan lima fase coming apart. Dalam setiap tingkatan itu terbentuk pola komunikasi yang berbeda yang menandai perubahan pola komunikasi dari Pramugari dan pasangannya, yaitu bagaimana suatu hubungan dimulai dalam tahapan coming together dan bagaimana hubungan tersebut memasuki tahapan coming apart yang dimulai dengan penurunan hubungan sampai hubungan tersebut berakhir.

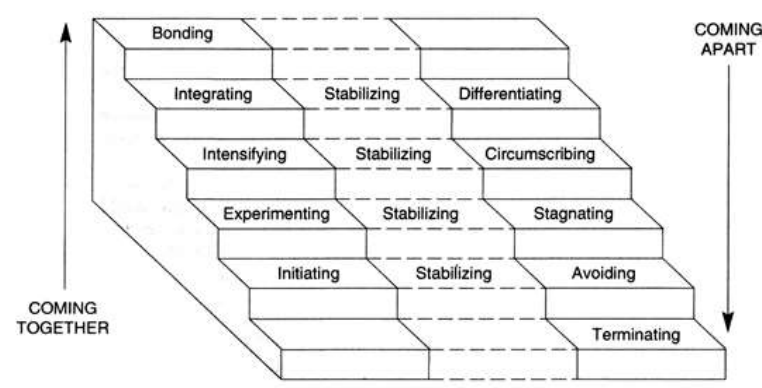

Gambar 1. Staircase Model of Interaction Stages Knapp (2014: 48)

Lima tahapan coming together tersebut adalah: Tahap Memulai (Initiating) merupakan usaha-usaha yang sangat awal yang kita lakukan dalam percakapan dengan seseorang yang baru kita kenal. Tujuannya adalah untuk mengadakan kontak dan menyatakan minat. Biasanya komunikasi dilakukan dengan hatihati dan konvensional pada tahap ini.; Tahap Penjajakan (Experimenting) adalah fase di mana kita memulai komunikasi dengan mengangkat topik percakapan dengan tujuan untuk mengenal satu sama lain. Biasanya kita banyak mengajukan pertanyaan dan berbasa- 
basi. Tujuan komunikasi di sini adalah untuk mengetahui kesamaan dan perbedaan di antara kedua belah pihak.; Penggiatan (Intensifying) menandai awal keintiman, berbagi informasi pribadi, dan awal informalitas yang lebih besar. Perubahan terjadi dalam perilaku komunikasi verbal maupun nonverbal. Perubahan komunikasi nonverbal menjadi lebih intim terlihat dari kedekatan fisik seperti berpegangan tangan, dan kontak mata yang lebih sering.; Pengintegrasian (Integrating) terjadi saat dua orang mulai menganggap diri mereka sebagai pasangan. Keduanya secara aktif memupuk semua minat, sikap dan kualitas yang tampaknya membuat mereka unik sebagai pasangan. Mereka mungkin juga melakukan hal itu dengan cara simbolik misal bertukar cincin, atau menyebut suatu lagu sebagai 'lagukita'.; Pengikatan (Bonding) adalah tahap yang lebih formal atau ritualistik, bisa berbentuk pertunangan atau perkawinan, namun "berhubungan tetap" juga merupakan suatu bentuk pengikatan. Pasangan sepakat menerima seperangkat aturan atau norma yang mengatur hubungan mereka, dan mereka kini lebih sulit untuk berpisah.

Lima tahap berikutnya menggambarkan kemerosotan yang dapat terjadi dalam hubungan yang telah mencapai tahap pengikatan. Perbedaan (Differentiating) terjadi bila dua orang menetapkan bahwa mungkin hubungan mereka ingin dibatasi. Sekarang mereka mulai memusatkan perhatian pada perbedaan-perbedaan daripada kesamaankesamaan. Fase ini ditandai dengan seringnya terjadi perselisihan.

Tahap pertama adalah tahap pembatasan (Circumscribing) adalah suatu tahap yang menunjukkan bahwa pasangan mulai mengurangi frekuensi dan keintiman dalam berkomunikasi dan berinteraksi. Topiktopik tertentu yang cenderung menimbulkan suasana menjadi panas berusaha dihindari. Berikutnya adalah tahap Stagnasi (Stagnating) menunjukkan kemerosotan hubungan yang semakin jauh sehingga mereka mencoba untuk bertahan dengan alasan seperti keagamaan, keuangan, atau demi kebaikan anak-anak, dan faktorlainnya berhubungan dengan tidak adanya lagi dayatarik terhadap pasangannya. Komunikasi verbal dan nonverbal semakin menyerupai komunikasi antara dua orang asing. Kemudian tahap Penghindaran (Avoiding) adalah suatu taktik untuk meminimalkan penderitaan atas pengalaman hubungan yang merosot sama sekali. Perpisahan secara fisik sering terjadi, atau walaupun mereka masih tinggal bersama/berdekatan mereka mampu menjaga kontak secara minimum. Dan terakhir tahap Pemutusan (Terminating) adalah tahap final dalam suatu hubungan. Menurut Knapp, pemutusan hubungan bisa terjadi setelah suatu percakapan serius maupun setelah tumbuhnya keintiman sepanjang hidup. Umumnya, semakin lama dan semakin penting hubungan itu, semakin menyakitkan perpisahan yang terjadi. Semua tahapan diatas digambarkan dalam bentuk contoh komunikasi dalam bentuk percakapan pada tabel 1 .

Tabel 1. Model of Interaction Stages

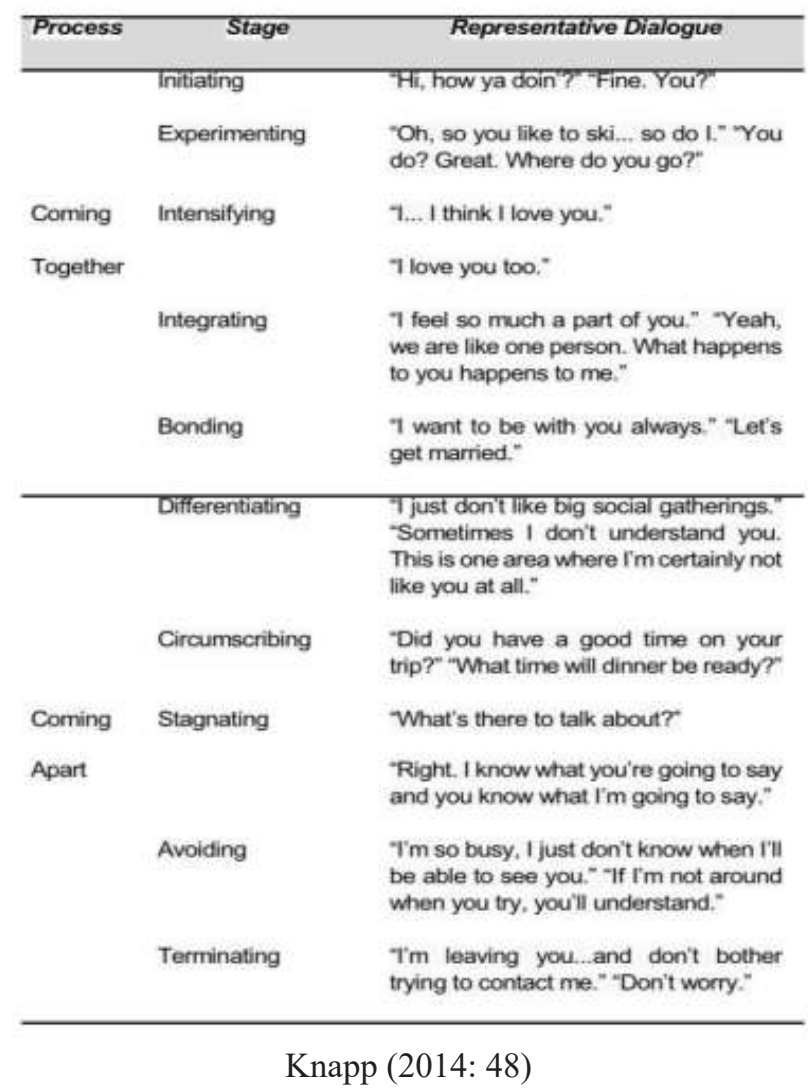




\section{METODOLOGI}

Penelitianyang dilakukanolehpenelitiadalah penelitian fenomenologi dengan menggunakan pendekatan kualitatif, dimana dalam penelitian ini peneliti terjun langsung ke lapangan untuk mengumpulkan atau mendapatkan data dari pengalaman narasumber yang sesuai dengan masalah yang ingin diteliti secara tatap muka. Penelitian kualitatif ini bertujuan untuk menjelaskan fenomena secara mendalam melalui pengumpulan data sedalam-dalamnya, disamping itu disini lebih ditekankan pada kualitas maka besarnya populasi atau sampling tidak diutamakan. Teknik pengumpulan data primernya adalah melalui wawancara, dan data sekundernya menggunakan buku-buku dan beberapa jurnal ilmiah. Creswell (Sugiyono, 2016:15) mengatakan bahwa hasil penelitian ini lebih menekankan pada generalisasi.

Penelitian ini, menggunakan paradigma kontruktivisme agar dapat melihat pola komunikasi yang terbentuk pada setiap tahapan komunikasi suami istri. (Eriyanto, 2002:13). Informan yang yang digunakan dalam penelitian ini berjumlah empat orang. Kriteria dari informan dalam penelitian ini adalah; Wanita dengan profesi pramugari yang sudah menikah, memiliki jabatan manajer (cabin manager), memiliki bawahan serta atasan, dan bekerja dengan waktu yang tidak umum serta harus meninggalkan keluarga dalam jangka waktu tertentu; berusia 30-43 tahun, karena kriteria jabatan berada di tingkat middle to top management ada pada rentang usia tersebut.; bertempat tinggal di Abu Dhabi, dan Jakarta; dengan kelas sosial menengah keatas. Kriteria tersebut didasarkan pada fenomena terdekat yang terjadi dan diamati oleh peneliti yang juga bermukim dan berprofesi sebagai pramugari di negara Uni Emirat Arab. Penelitian ini difokuskan pada pola komunikasi dari elemen yang terdapat pada coming together dan coming apart. Hasilnya akan dikaitkan dengan pola komunikasi yang terjadi sejak tahap memulai hubungan sampai tahap berpisah.

Narasumber dalam penelitian ini adalah pramugari A (informan satu), berusia 36 tahun, sudah bercerai, dan memiliki posisi sebagai Cabin Manager.; Pramugari B (informan dua), berusia 43 tahun, bercerai dan sudah menikah lagi, dan memiliki posisi Cabin Manager.; Pramugari C (informan tiga), berusia 42 tahun, menikah, memiliki posisi sebagai Cabin Manager. Memiliki hambatan komunikasi dalam penikahannya dan sedang mengikuti konseling pernikahan untuk menyelamatkan pernikahannya.; Pramugari D (informan empat), berusia 39 tahun, memiliki posisi sebagai Cabin Manager, menikah tetapi sudah berpisah, belum memutuskan untuk bercerai.

\section{HASIL DAN PEMBAHASAN}

Initiating. Pramugari A mengenal ex suami ditempat bekerja yang sama pada saat bertugas terbang untuk pertama kalinya. Percakapan dimulai dari menanyakan bagaimana kesan pertama kali terbang. Pramugari B memulai perkenalan di pesawat dengan bertukar kartu nama. Komunikasi awal melalui chat dimana ex suami mengucapkan terima kasih atas pelayanan yang sangat bagus. Pramugari C mengenal suaminya pertama kali saat sedang menginap di hotel tempat suaminya bekerja. Percakapan ringan dimulai ketika melakukan check-in karena Pramugari $\mathrm{C}$ sering bertugas untuk terbang ke kota dimana hotel tersebut berada dan suaminya selalu menangani proses check-in. Pramugari D berkenalan dengan suami sejak SMA saat ospek, dimana mereka harus berkenalan dengan teman lawan jenis yang sekelas kemudian saling mengisi biodata singkat sebagai tugas.

Experimenting. Pramugari A memiliki ketertarikan yang sama dengan ex suami yaitu kulineran, sehingga seringkali janjian untuk terbang bersama dengan alasan untuk menjelajahi kuliner di negara berbeda. Ex suami Pramugari B melakukan pendekatan dengan sering mengajak bertemu di kedai kopi karena sama-sama penikmat kopi. Pramugari C menemukan ketertarikan dengan suami karena keduanya suka travelling keliling dunia. 
Pramugari D memulai hubungan dekat dengan suami saat ikut ekstra kurikuler paskibraka.

Intensifying. Ex suami pramugari Apertama kali menyatakan rindu saat selama satu bulan tidak mendapatkan jadwal terbang bersama. Pramugari B mengatakan bahwa ex suaminya sangat perhatian dan sering memuji. Suami Pramugari C selalu menyediakan bunga dengan ucapan "welcome back, have a good rest" saat pramugari $\mathrm{C}$ menginap dihotelnya. Pramugari $\mathrm{D}$ masih ingat saat suami memberikan kaset lagu DEWA yang disertai dengan surat cinta.

Integrating. Pramugari A dilamar oleh ex suami saat terbang bersama sebagai tanda keseriusan. Ex suami Pramugari B membeli properti atas nama bersama sebelum menikah. Pramugari $\mathrm{C}$ dan suaminya memiliki tabungan bersama untuk persiapan menikah. Pramugari D bertukar cincin dengan suami saat sebelum lulus SMA sebagai tanda keseriusan untuk menikah.

Bonding. Pramugari A, B, C, dan D memasuki tahap pernikahan sebagai bentuk peningkatan keseriusan dari komitmen sebelumnya ke tahap pengesahan hubungan secara legal yaitu pernikahan.

Differentiating. Pramugari A mulai merasakan perbedaan saat ex suami pindah bekerja di perusahaan lain, dimana ex suami lebih sering menghabiskan waktu dengan teman barunya, sedangkan Pramugari A memiliki jadwal terbang yang sangat padat. Pramugari B menyebut ex suaminya workaholic baik dirumah maupun di kantor, perkataan seperti "saya sangat sibuk" sering diucapkannya, sehingga membuat pramugari B lebih memilih untuk memiliki jadwal terbang yang padat juga. Pramugari $\mathrm{C}$ merasakan perubahan dalam berkomunikasi dengan suami disaat suami mendapatkan promosi jabatan. Perkataan seperti "saya ingin memiliki tabungan pribadi" pernah diucapkan. Pramugari D merasakan perubahan dalam berkomunikasi saat menyatakan ingin berhenti bekerja dan ingin segera memiliki anak. Suami pramugari D agak mulai menghindar dengan cara menghabiskan waktu dirumah dengan bermain online game atau menonton televisi.

Circumscribing. Pertengkaran sering terjadi ditahap ini, Pramugari A dan ex suami pernah mengucapkan "urus saja hidup masing-masing". Sementara Pramugari B dan ex suaminya lebih memilih diam dan hanya berkomunikasi seperlunya saja seperti "saudara/orangtua akan berkunjung dalam waktu dekat, sebaiknya kita siapkan hotel saja". Pramugari $\mathrm{C}$ sering bertengkar yang disertai dengan pernyataan "saya ini istri kamu" atau "saya ini suami, bukan barang yang kamu miliki". Berbeda dengan Pramugari D dan suaminya sering menghabiskan waktu dalam diam walaupun duduk di mobil yang sama maupun saat berkunjung ke restoran.

Stagnating. Komunikasi Pramugari A dan B tidak ada perubahan kearah yang lebih baik ditahap ini. Saling menyalahkan dan lebih suka berasumsi sendiri dibandingkan bertanya langsung. Pramugari C dan suami mencari solusi dengan berkonsultasi melalui konseling pernikahan. Sementara Pramugari D dan suami tidak tahu harus berbuat apa di tahap ini.

Avoiding. PramugariAdan B memasuki tahap ini dimana keduanya tidak lagi berkomunikasi secara langsung dengan ex suami, melainkan melalui pengacara pernikahan. Pramugari D memasuki tahap ini melalui pisah rumah tetapi belum sepakat untuk bercerai. Pramugari C tidak memasuki tahap ini.

Terminating. Hanya pramugari A dan B yang memasuki tahap ini dan mengakhiri pernikahannya.

\section{Pembahasan}

Objek wanita dengan profesi pramugari digunakan peneliti sebagai informan. Profesi pramugari khususnya pada maskapai internasional memiliki jadwal kerja yang padat sehingga kurangnya waktu bersama pasangan. Komunikasi menjadi hambar dan tanpa disadari kemerosotan dalam hubungan pun terjadi. Setiap pramugari dan pasangannya mengalami 
semua elemen yang terdapat dalam tahap coming together. Semua pasangan tersebut saling membentuk perasaan cinta satu sama lain melalui pola komunikasi yang terjalin sejak perkenalan.

Komunikasi yang baik dengan pasangan ditandai dengan membahas hal-hal yang berkaitan dengan keseharian merupakan kebiasaan yang dapat memperat hubungan dimana terdapat keterbukaan (openness), empati (empathy), dukungan (supportiveness), rasa positif (positives), dan kesetaraan (equality) yang diberikan terhadap pasangan satu sama lain. Hal ini sejalan dengan penelitian Oktariani (2018) menyimpulkan bahwa beberapa faktor yang mempengaruhi komunikasi dalam perkawinan antara lain, be nice, communicate, be open, give assurance, be positive dan focus on improving yourself digunakan untuk menjalin komunikasi serta mempertahankan komitmen diantara masingmasing pasangan.

Hubungan diawali dengan komunikasi dan interaksi yang baik. Tahapan coming together dari intiating, experimenting, intesifying, integrating sampai mencapai tahap bonding ditunjukkan melalui ketertarikan, menemukan banyak kesamaan visi sehingga memutuskan untuk berkomitmen lebih serius. Komitmen terbentuk dalam tahap bonding yang menunjukan keseriusan karena para pasangan saling meyakini pentingnya hubungan yang dijalani dan mengabdikan diri serta berusaha untuk menjaga hubungan tersebut.

Tahapan coming together yang indah seperti terlupakan saat timbul awal perbedaan yang mulai terjadi. Tanpa disadari kemerosotan hubungan dimulai melalui kurangnya waktu berkomunikasi dan berinteraksi sehingga perbedaan yang timbul seringkali bisa menyebabkan pertengkaran dimana semua pramugari pernah mengalami hambatan berkomunikasi dengan pasangannya sampai menyebabkan krisis dalam pernikahannya.

Perbedaan dan perubahan sikap akan terus terjadi seiring berjalannya usianya pernikahan.
Perubahan akan lingkungan kerja, tekanan pekerjaan, pertemanan dan bertambahnya tanggung jawab dari setiap individu dapat saja mempengaruhi cara berkomunikasi yang akan berdampak pada perubahan sikap terhadap pasangan.

Sesuai dengan fokus penelitian yang menggunakan komunikasi interpersonal dalam relational development model melihat tahapan pola komunikasi dan interaksi sampai menyebabkan krisis dalam pernikahan. Komunikasi interpersonal merujuk pada kegiatan berkomunikasi yang terjadi secara langsung di antara dua orang dalam mempertahankan hubungan walau terkadang hal-hal yang dibahas keduanya tidak selalu hal penting tetapi harus terus diterapkan dalam tiap tahapan komunikasi coming together, sehingga saat perbedaan (differentiating) timbul dapat segera di selesaikan.

Dalam relational development model, Knapp menggambarkan hubungan interpersonal melalui pola komunikasi dan interaksi hubungan dalam sebuah siklus, dari perkenalan, menuju kebersamaan, menuju perpisahan, dan kemungkinan kembali menuju kebersamaan. Pada setiap tahapnya, terdapat pola komunikasi yang memainkan peran yang besar dalam memasuki tahap selanjutnya. Sebagai contoh pramugari $\mathrm{C}$ mampu melewati krisis saat menyadari bahwa mereka membutuhkan bantuan konsultasi perkawinan, sehingga tahapan coming apart berhenti di stagnating.

Semua pramugari mengalami tahapan coming apart tetapi tidak melewati semua elemen dalam tahap tersebut. Hanya dua pramugari saja yang sampai memasuki elemen terminating dan berakhir dengan perceraian. Dimana tidak ada komunikasi lagi dan masingmasing individu saling tertutup, dingin, serta cendurung menutup diri.

Hanya Pramugari $\mathrm{C}$ yang bertahan di elemen avoiding, memutuskan untuk cooling down dengan cara hidup berpisah dalam jangka waktu tertentu. Pramugari C mengungkapkan bahwa 
komunikasi dengan pasangannya hampir tidak ada sehingga menimbulkan keraguan untuk melanjutkan pernikahan atau bercerai.

Hasil dari penelitian, semua pramugari dan pasangannya mengalami semua elemen tahapan coming together yang memiliki pola interaksi dan komunikasi yang terdapat dalam relational development model. Dimana didalamnya terdapat ciri-ciri dari komunikasi interpersonal. Dalam tahapan coming together tergambar bahwa ada elemen openness, empathy, supportivenness, positives dan equality dalam memasuki tiap tahapan coming together.

Elemen equality timbul pada Pramugari C saat hubungan memasuki tahap integrating melalui pembicaraan untuk membuka tabungan bersama. Dalam tahap intensifying dan integrating tergambar bahwa Pramugari A dan ex suami terdapat elemen openness melalui ungkapan rasa rindu terhadap satu sama lain, sedangkan Pramugari D diberikan kaset DEWA 19 disertai dengan surat cinta. Rasa positives ditunjukan dalam tahap experimenting dimana Pramugari B dan ex suami sama-sama penikmat kopi, sehingga sering menghabiskan waktu bersama di kedai kopi untuk mencoba varian kopi yang berbeda. Sedangkan Pramugari $\mathrm{C}$ dan pasangannya memupuk elemen positives dan suppportivenness dengan sering melakukan travelling bersama. Elemen empathy ditunjukkan dalam tahap intesifying dimana suami Pramugari $\mathrm{C}$ selalu memberikan bunga dengan ucapan "welcome back, have a good rest" saat menginap di hotel tempat suaminya bekerja.

Tahapan coming apart juga dialami oleh semua pramugari, tetapi tidak semuanya memasuki elemen terminating. Pramugari $\mathrm{C}$ dapat mengatasi krisis pernikahannya dengan mengikuti konseling pernikahan., sedangkan Pramugari D masih bertahan dalam ikatan pernikahan walaupun hidup berpisah dengan suami. Hanya pramugari A dan B yang mengalami tahapan terminating. (differentiating) timbul, diawali dengan adanya lingkungan baru, kesibukan kerja yang bertambah, dan tidak memelihara komunikasi yang baik. Seringnya perkataan seperti "saya sangat sibuk" diucapkan oleh ex suami Pramugari B dan kurangnya supportivenness dalam bentuk pengertian dari Pramugari B atas kesibukan ex suami. Hal ini terus berlangsung dan menimbulkan jarak dalam berkomunikasi. Berkurangnya elemen openness ditunjukkan oleh pramugari A saat ex suami pindah kantor dan lebih sering menghabiskan waktu dengan lingkungan barunya, Pramugari A sering menanyakan "kenapa sering menghabiskan waktu diluar?" dan biasanya diakhiri dengan pertengkaran. Elemen equality juga hilang saat suami Pramugari $\mathrm{C}$ mengucapkan perkataan "saya ingin memiliki rekening pribadi" dalam pertengkarannya disaat suami mendapatkan promosi jabatan. Pramugari C mengusulkan suami harus berkontribusi dalam jumlah yang sama dengannya untuk kebutuhan seharihari. Kurangnya empathy ditunjukkan oleh suami Pramugari D saat percakapan untuk segera memiliki anak diangkat menjadi topik pembicaraan serius. Suami lebih memilih menyibukkan bermain game online dan menonton televisi saat berada dirumah. Komunikasi sangat terbatas sampai berada pada tahap krisis dan berpisah rumah.

Keterkaitan teori konstruksi sosial dalam relational development model pada tahapan coming together terbentuk saat setiap informan mampu menjawab hal apa yang menarik dari diri setiap informan yang membuat pasangan menyukai informan-informan tersebut yang dijelaskan dalam tabel 2.

Tabel 2.

Konstruksi sosial dalam tahap coming together

\begin{tabular}{ll}
\hline Informan & Konstruksi sosial dalam tahap coming together \\
\hline Informan 1 & Luwes layaknya perempuan jawa \\
Informan 2 & Mandiri \\
Informan 3 & Pandai bergaul \\
Informan 4 & Percaya diri \\
\hline
\end{tabular}

Sumber: data wawancara (2020)

Elemen positives hilang saat perbedaan 
Setiap informan memiliki pandangan bahwa hambatan yang timbul dalam sebuah pernikahan bisa diusahakan untuk dicari jalan keluarnya yang tergambar dari usahausaha yang dilakukan oleh setiap informan. Pandangan itu digambarkan dalam proses wawancara dan disimpulkan melalui tabel 3 mengenai konstruksi sosial komunikasi dalam tahap maintaining relationship.

Tabel 3.

Konstruksi sosial komunikasi dalam tahap maintaining relationship

\begin{tabular}{ll}
\hline Informan & $\begin{array}{l}\text { Konstruksi sosial dalam tahap } \\
\text { maintaining relationship }\end{array}$ \\
\hline Informan 1 & $\begin{array}{l}\text { Mengajak berbicara dari hati ke hati, } \\
\text { dan mengajak makan diluar. }\end{array}$ \\
Informan 2 & $\begin{array}{l}\text { Mengajak berlibur untuk mencari } \\
\text { solusi demi menyelamatkan } \\
\text { pernikahan. }\end{array}$ \\
Informan 3 & $\begin{array}{l}\text { Keutuhan pernikahan harus } \\
\text { diusahakan dan dipertahankan. }\end{array}$ \\
Informan 4 & $\begin{array}{l}\text { Keutuhan pernikahan harus } \\
\text { diusahakan dan dipertahankan. }\end{array}$ \\
\hline
\end{tabular}

Sumber: data olahan pribadi (2020)

Sementara, dalam tabel 4 berisi mengenai bagaimana konstruksi sosial terbentuk dari setiap informan dalam tahap coming apart, menunjukkan cara pandang yang berbeda dalam menyikapi kemorosotan hubungan pernikahan. Beberapa diantaranya mengakhiri pernikahannnya dengan alasan tertentu yang merupakan hasil dari konstruksi sosial tersebut.

Hasil diatas menunjukkan tiga temuan tentang konstruksi sosial yang terbentuk dari proses pola komunikasi pramugari maskapai internasional dengan pasangannya ketika berada dalam tahap-tahap membangun relasi yang intim (coming together), tahap-tahap mempertahankan (maintaining relationship) relasi yang intim dalam pernikahan, dan pada tahap-tahap mengakhiri relasi (coming apart) yang intim dalam pernikahannya.

\section{SIMPULAN}

Berdasarkan analisis, pembahasan, dan temuan data, dalam penelitian ini menunjukkan tiga temuan tentang konstruksi sosial yang
Tabel 4.

Konstruksi sosial komunikasi dalam tahap coming apart

\begin{tabular}{|c|c|}
\hline Informan & $\begin{array}{l}\text { Konstruksi sosial dalam tahap } \\
\text { coming apart }\end{array}$ \\
\hline Informan 1 & $\begin{array}{l}\text { - Menerima keputusan untuk } \\
\text { bercerai karena tidak ada yang } \\
\text { dapat dipertahankan. } \\
\text { - Tidak ada alasan kuat untuk } \\
\text { mempertahankan } \\
\text { pernikahannya. }\end{array}$ \\
\hline Informan 2 & $\begin{array}{l}\text { Memilih untuk bercerai karena } \\
\text { tujuan pernikahan baginya adalah } \\
\text { memiliki keturunan. }\end{array}$ \\
\hline Informan 3 & $\begin{array}{l}\text { - Mencari bantuan konsultasi } \\
\text { pernikahan. } \\
\text { - Pernikahan adalah komitmen } \\
\text { seumur hidup sampai maut } \\
\text { memisahkan. }\end{array}$ \\
\hline Informan 4 & $\begin{array}{l}\text { Pernikahan adalah komitmen } \\
\text { seumur hidup sampai maut } \\
\text { memisahkan. }\end{array}$ \\
\hline
\end{tabular}

Sumber: data olahan pribadi (2020)

terbentuk dari proses pola komunikasi pramugari maskapai internasional dengan pasangannya ketika berada dalam tahaptahap membangun relasi yang intim (coming together), tahap-tahap mempertahankan (maintaining relationship) relasi yang intim dalam pernikahan, dan pada tahap-tahap mengakhiri relasi (coming apart) yang intim dalam pernikahannya.

Pertama, pola komunikasi antara pramugari dengan pasangannya cenderung tidak terlalu mendalam, pada tahapan coming together dimana hal-hal penting seperti rencana memiliki anak tidak terlalu dibahas secara mendalam sehingga pada saat setelah menikah terjadi hambatan komunikasi yang timbul dari pandangan suami terhadap istrinya dalam hal memiliki keturunan.

Kedua, pada tahapan maintaining relationship, pramugari berharap untuk dapat menghabiskan waktu bersama suami ketika libur, sehingga apabila suami memiliki ritme kerjayang tidak teraturjuga, akanmenjadi sangat sulit bagi keduanya untuk memiliki kualitas waktu yang baik dalam berkomunikasi dan 
berinteraksi sehingga seringkali menimbulkan hambatan dalam berkomunikasi yang bisa menyebabkan krisis dalam pernikahannya.

Ketiga, pola komunikasi yang terbentuk pada tahapan coming apart merupakan hasil konstruksi sosial yang dialami dari setiap pramugari melalui komunikasi dan interaksi antara pramugari dengan suaminya, sehingga memutuskan untuk bercerai atau mempertahankan pernikahan.

Wanita dengan profesi pramugari tanpa di sadari mengalami proses konstruksi sosial yang sebenarnya merupakan hasil dari jaringan yang terbentuk oleh lingkungan sosial dimana pramugari itu berada. Proses tersebut secara sadar atau tidak telah membentuk pandangan mengenai wanita dengan profesi pramugari, khususnya di maskapai internasional yang memiliki kesulitan dalam membagi waktu yang terkadang menimbulkan hambatan dalam berkomunikasi dengan pasangannya. Hal menarik ditemukan, dengan kepandaian dan keluwesannya saat berkomunikasi dan bernegosiasi ketika harus menjalankan perannya sebagai manajer kabin yang terbilang terampil, berbanding terbalik ketika pramugari kembali kerumah dan menjalankan perannya sebagai istri.

\section{DAFTAR PUSTAKA}

Basrowi \& Sukidin. (2002). Metode Penelitian Kualitatif Perspektif Mikro. Surabaya. Insan Cendikia.

Brody, N., Levebre, L., \& Blackburn, K. (2016). SocialNetworking SiteBehaviorsAcross the Relational Lifespan: Measurement and Association With Relationship Escalation and De-escalation, from https://journals.sagepub.com/doi/ full/10.1177/2056305116680004

Dewi, N. R., \& Sudhana, H. (2013). Hubungan Antara Komunikasi Interpersonal Pasutri Dengan Keharmonisan Dalam Pernikahan. Jurnal Psikologi Udayana, 1(1), 22-31.
Eriyanto. 2002. Analisis Framing, Konstruksi, Ideoligi, dan Politik. Yogyakarta:LKis.

Hurlock, E. B. 2002. Psikologi perkembangan: suatu pendekatan sepanjang rentang kehidupan (edisi kelima) (Terjemahan). Jakarta: Penerbit Erlangga.

Knapp, M. L., Vangelisti, A.L., \& John P. Caughlin, J. P. (2014). Interpersonal Communication And Human Relationship, seventh edition.

Littlejohn, S. W \& K. A. Foss. 2009. Teori Komunikasi, edisi 9. Jakarta: Salemba Humanika.

Luthfi, M. (2017). Komunikasi Interpersonal Suami dan Istri Dalam Mencegah Perceraian di Ponorogo, from https:// ejournal.unida.gontor.ac.id/index.php/ ettisal/article/viewFile/1413/1038

Oktariani, M. (2018). Pola Komunikasi Pasangan Long Distance Relationship Dalam Mempertahankan Hubungan Melalui Media Sosial Line. WACANA, Jurnal Ilmiah Ilmu Komunikasi. 17(2), 193-200. https://doi.org/10.32509/ wacana.v17i2.631

Paputungan, F. (2015). Kepuasan Pernikahan Suami Yang Memiliki Istri Berkarir, from https://www.academia. edu/22785398/kepuasan_pernikahan_ suami_yang_memiliki_istri_berkarir

Parrott, L., Parrott, L. (1995). Saving Your Marriage Before It Starts: Seven Questions to Ask Before (and After) You Marry. Grand Rapids, Michigan: Zondervan.

Saunders. (2017, December 5). You're More Likely To Get Divorced If You Or Your Partner Has One Of These 8 Jobs. Diperoleh dari https://www.prevention. com/sex/a20509570/jobs-high-divorcerate/

Sugiyo. (2005). Komunikasi Antar Pribadi. Semarang: UNNES PRESS.

Sugiyono. (2016). Metode Penelitian Kuantitatif, Kualitatif dan R\&D. 
Bandung: PT Alfabet.

Ternyata, Ini 7 Jenis Pekerjaan dengan Tingkat Perceraian Tinggi, https://www. liputan6.com/lifestyle/read/3215279/ ternyata-ini-7-jenis-pekerjaan-dengantingkat-perceraian-tinggi
Yuliati, N. (2012). Pemaknaan, Penyesuaian, dan Komunikasi dalam Perkawinan pada Dosen Perempuan. MIMBAR: Jurnal Sosial dan Pembangunan, 28(2), 145-156. 